\title{
Indonesia as a transit country in irregular migration to Australia
}

\section{Graeme Hugo, George Tan and Caven Jonathan Napitupulu}

One important element in the growing complexity of international migration is the increasing role of countries of transit. Movement trajectories in contemporary migrations can extend over long periods of time and a number of intermediate locations before reaching a final destination. This is especially the case for asylum seekers and for irregular migration. In both of these cases, transit countries are increasingly significant; however, the bulk of migration research is focused on the destination, and to a lesser extent, the origin country.

Several Asian countries are playing increasingly significant roles as transit locations. This chapter focuses on one country, Indonesia, which, until the commencement of the Australian Government's military-led 'Operation Sovereign Borders', in September 2013, ${ }^{1}$ functioned as a transit point for asylum seekers and irregular migrants seeking to land on Australia's northern shores.

1 The objective of Operation Sovereign Borders was primarily to deter IMAs from seeking asylum on Australian territories by intercepting and turning around suspected illegal entry vessels (SIEVs), and by denying resettlement in Australia by assessing asylum claims in a third country, resettling those found to be refugees in a third country. 
This chapter is based largely on field studies undertaken in Indonesia between 2012 and 2014. The centrepiece was a survey of 119 intending irregular maritime arrivals (IMAs). These subjects were located in Indonesian detention centres or were living in Indonesian communities located in Medan, Tanjung, Pinang, Jakarta, Kupang and in Puncak, a former colonial hill station area located in the mountains to the south of Jakarta (Figure 7.1). A structured questionnaire was used, which asked questions about the IMAs' characteristics, their experience of migration, their motivations and intentions relating to moving to Australia. In addition, a substantial number of informant interviews were conducted in Indonesia with people involved in the migration process or interacting with transiting migrants.

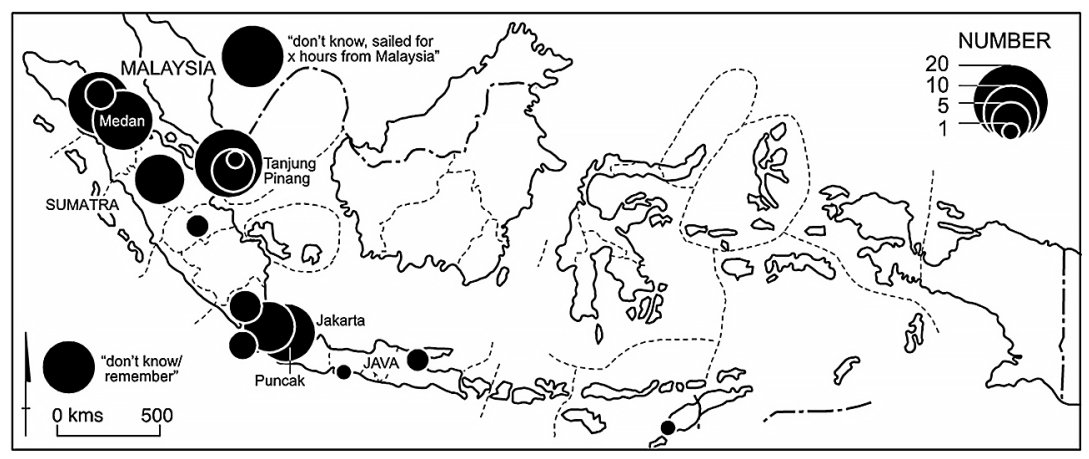

Figure 7.1: Intending asylum seekers in Indonesia: Arrival location and place of interview of respondents to survey

Source: Image produced by the Department of Geography, Environment and Population at the University of Adelaide, for this study.

The respondents to the survey were identified within detention centres, in accommodation provided by the International Organization for Migration (IOM), and in communities in several locations in Indonesia, Jakarta, Puncak and adjoining areas in West Java, Timor, northern Sumatra, Riau and South Sumatra. Once identified, they were approached and asked if they would agree to be interviewed. The agreement was difficult to get, given their precarious situation. The clandestine nature of irregular migration makes it challenging to survey this migrant group as it was not uncommon for research subjects to view researchers with some degree of suspicion and apprehension (e.g. United Nations Office on Drugs and Crime [UNODC], 2009 , p. 5). As Düvell, Triandafyllidou, and Vollmer (2008, p. 7) note, the fears of a smuggled migrant that $s /$ he will be identified upon participation in a study can be a research obstacle, as it is usually associated with fears of 
reprisal from smugglers and authorities, in the possible form of deportation or imprisonment. Accordingly, large numbers had to be approached to get the number of completed interviews obtained.

\section{Transit migration in Asia}

Transit migration can be seen as part of a global situation in which international migration has become more complex than the 'assimilation narrative' (Ley \& Kobayashi, 2005) in which migration is seen as a oneoff, more or less permanent, displacement from an origin to a single destination and the process of adjustment to that destination. There are now elements of coming and going between origin and destination, temporary and circular migration, migration to third, fourth and more countries and diaspora linkages between origins and destinations.

It is important to note the strong association of transit migration with two important forms of international migration in the contemporary world: forced migration (especially refugee and asylum seeker movement but also that associated with disasters); and irregular migration.

Most forced migrants are not able to move directly to a place of permanent resettlement due to the largely unplanned and unanticipated nature of the move and the sudden circumstances which precipitate the move. Accordingly, they often move to a temporary haven which Kunz (1973) describes as a 'midway to nowhere' situation to emphasise the precariousness, uncertainty and temporariness of their stay there.

Often migrants cannot move directly to their intended final destination because they lack the appropriate documentation or are not able to meet the entry requirements of that destination. This is especially the case when the destination is a nation belonging to the Organisation for Economic Co-operation and Development (OECD), with sophisticated border entry controls and highly controlled migration systems. Australia is such a nation, and a combination of its island geography, isolation, highly developed immigration bureaucracy and institutions and modern technologies of surveillance mean that it can control very effectively the number and characteristics of immigrants.

A country of transit can be a place where irregular migrants can arrange their entry to their intended destination, but it is also one of the places where they are at risk of repatriation. 


\section{The Indonesian context}

Indonesia in many ways is a quintessential transit migration country in that it meets almost all the defining characteristics of a transit country. These include:

- Its intermediate geographical location between the Middle East, Africa and Asia on the one hand, and Australia on the other. It is comparable to Turkey and Russia, in that, for those countries, being located on the edges of Western Europe has meant that they have become important transit locations for irregular migrants from Asia and Africa and the Middle East intending to enter Europe.

- Its archipelago geography, comprising more than 3,000 islands. This presents virtually unlimited opportunities to enter Indonesia by boat without detection.

- Its strong historical linkages, involving centuries of population movement and settlement, with the main origin countries (South Asia and the Middle East) of many groups seeking to enter Australia and seek asylum.

- Its complex contemporary migration system, which not only involves important flows to the origins of asylum seekers and to other transit nations involved in their movement, but has seen the development of a substantial migration industry.

- A system of government in which corruption and bribery play a significant role, which opens up possibilities, not only for staying in Indonesia, but also for facilitating onward migration.

It is the world's fourth largest country by population, and despite recent rapid economic growth and fertility decline, it has a substantial labour surplus, especially of low-skilled, poorly educated workers. Accordingly, there has been significant emigration with the largest group being lowskilled temporary contract labour migrants.

The importance of Malaysia and the Middle East is especially important in creating migration corridors and linkages which have played a role in the contemporary movement of transit migrants with an intended destination of Australia. Malaysia and the Middle East are the origins of significant numbers of immigrants to Indonesia as well as the destination of emigrants. The importance of these migration flows in establishing corridors of movement along which asylum seekers and irregular migrants can move needs to be stressed. The connections which have been 
established between Indonesia and Malaysia are especially important. The Malaysia-Indonesia leg of the migration of IMAs intending to go to Australia is an important part of the migration process.

A key issue is that undocumented migration remains substantial, especially to Malaysia. While this process is complex, it has a number of elements which impinge on the movement of irregular migrants and asylum seekers using Indonesia as a transit nation with the intention of moving to Australia (Jones, 2000). Some of the major features are as follows:

- There are strong family, community and agent networks linking Malaysia and Indonesia, which facilitate migration.

- A strong 'industry' has developed, with multiple stakeholders at a range of levels ranging from the local to the international.

- There are a multiplicity of sea routes and coastal embarkation and disembarkation points in Malaysia and Indonesia.

- There is complicity of government officials in the irregular migration in both countries.

- Most of the movement, especially irregular migration, involves maritime journeys, much of it using erstwhile fishing boats, and there is substantial involvement of fishermen.

\section{Indonesia as a transit country for Intending IMAs to Australia}

Indonesia's function as a transit point for asylum seekers and irregular migrants who have Australia as an intended final destination is not new. Indonesia was an important transit point, along with Malaysia and other parts of Southeast and East Asia, for the wave of Indo Chinese boat people in the 1970s, 1980s and 1990s (Lander, 1996; Missbach, 2013).

Figure 7.2 presents results from a study by the Indonesian Directorate of Immigration of 40 Iraqi asylum seekers. This shows a pattern of initially flying to Kuala Lumpur in Malaysia and then moving to Indonesia through multiple channels.

The survey respondents' countries of origin are shown in Table 7.1. The bulk of respondents were from Afghanistan, Sri Lanka and Myanmar. Among these groups, only Sri Lankans have large numbers that sail directly from their homeland to Australia (Jayasuriya \& McAuliffe, 2013; Hugo \& Dissanayake, 2014). 


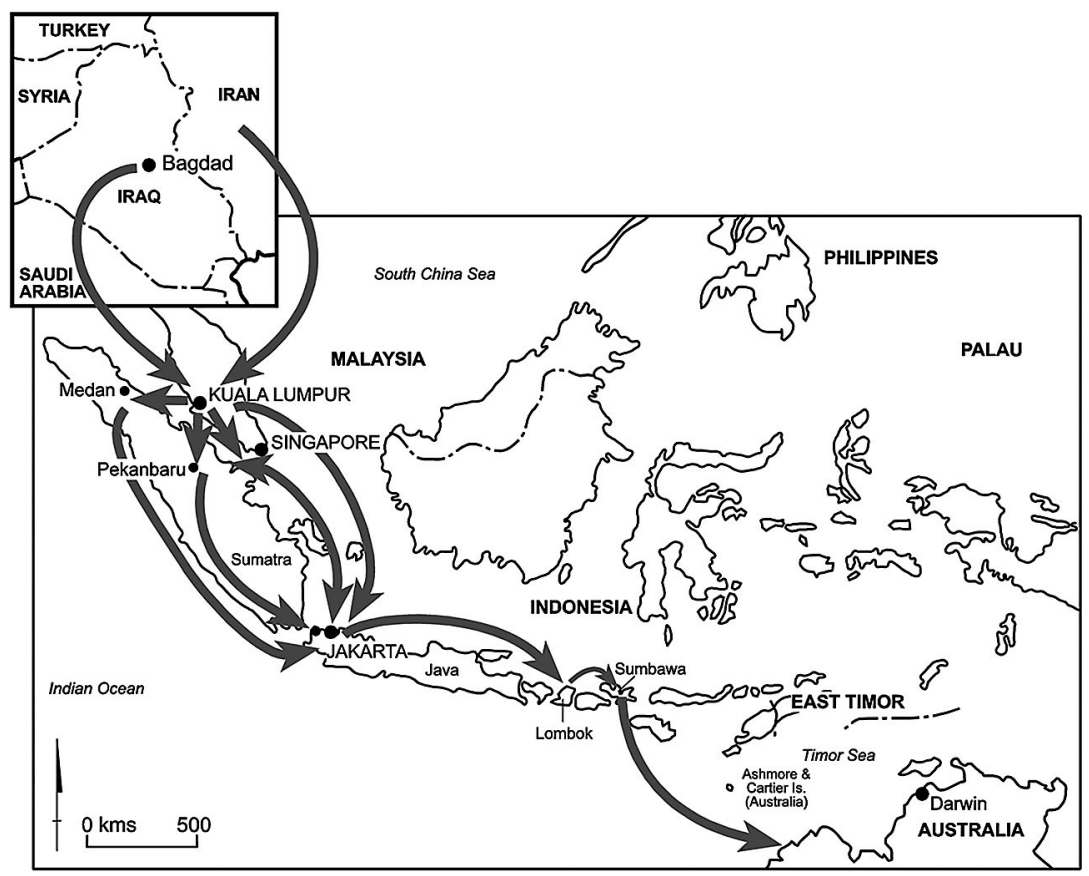

Figure 7.2: Trajectories of movement of 40 Iraqi asylum seekers, 2008

Source: Unpublished map supplied by Directorate General of Immigration, Jakarta, Indonesia. Reproduced with permission from Hugo and Napitupulu (2015, p. 224).

Table 7.1: Birthplace of survey respondents compared with IMAs in Australia, 2011-13

\begin{tabular}{|l|r|r|}
\hline \multirow{2}{*}{ Birthplace } & \multicolumn{2}{|c|}{ Survey } \\
\cline { 2 - 3 } & Number & \multicolumn{1}{|c|}{$\%$} \\
\hline Afghanistan & 65 & 52.8 \\
\hline Sri Lanka & 26 & 21.1 \\
\hline Myanmar & 15 & 12.2 \\
\hline Iraq & 7 & 5.7 \\
\hline Sudan & 4 & 3.3 \\
\hline Iran & 3 & 2.4 \\
\hline Palestine & 2 & 1.6 \\
\hline Somalia & 1 & 0.8 \\
\hline Total & 123 & 100.0 \\
\hline
\end{tabular}

Source: Transit migration survey $(2010,2012)$.

Note: The transit migration survey was conducted in 2010 and 2012 by C. J. Napitupulu for use in this study. 
All of the asylum seekers surveyed flew initially to Malaysia as 'tourists', since Malaysia offers visas upon arrival to nationals of more than 60 countries, especially those with Islamic populations, in order to facilitate tourism (Missbach \& Sinanu, 2011, p. 73). From Malaysia, they travel to Indonesia, which is the taking-off point for the final leg: a boat trip to Australia. These corridors of movement have become well established and a complex industry of interconnected agents has developed along the route to facilitate the migration from Malaysia to Indonesia. Many asylum seekers from Afghanistan, the most common origin, move initially to camps in Pakistan from where they negotiate with a people smuggler. Some asylum seekers travel directly to Indonesia, especially those like Iranians who could obtain a 30-day tourist visa on arrival. The removal of this visa has seen this direct flow to Indonesia dry up, and Iranians now travel via Kuala Lumpur. ${ }^{2}$ Some asylum seekers also move initially to Thailand, which has long been a hub for trafficking in the Asia region (Skrobanek, Boonpakdi \& Janthakeero, 1997). Many of the asylum seekers arriving initially in Malaysia then travel to Indonesia clandestinely by boat.

There is substantial boat traffic between Indonesia and Malaysia and an established migration industry linking them, with more than 2 million Indonesians working as international labour migrants in Malaysia, many of them undocumented (Hugo, 2011; Jones, 2000). In many cases, the people smugglers, who the asylum seekers negotiate with in their home country, only get them as far as Malaysia or Indonesia and it is then up to the asylum seekers to negotiate a passage to Australia with agents based in Malaysia, or especially Indonesia. The borders of Malaysia and Indonesia present little problem to asylum seekers as they seek to make their way to Australia. However, there are risks of detection and detention as well as experiencing exploitation at the hands of unscrupulous agents, police, officials and other groups in Malaysia and Indonesia.

The majority of survey respondents who transited in Indonesia entered illegally. Excluding respondents who unintentionally arrived, a significant 90.7 per cent $(\mathrm{n}=88)$ of respondents indicated that they entered illegally, compared with 9.3 per cent $(n=9)$ of respondents who entered legally. As Table 7.2 shows, the main reason for entering Indonesia illegally (as indicated by 84.1 per cent of respondents) was because they were not able to travel legally.

2 This pattern may well change again, because in 2014 the Malaysian government removed access for Iranians to Visa on Arrival facilities. 
Table 7.2: Reasons for entering Indonesia illegally

\begin{tabular}{|c|c|c|c|c|c|c|c|c|c|c|}
\hline & \multicolumn{2}{|c|}{$\begin{array}{l}\text { Afghanistan } \\
(n=61)\end{array}$} & \multicolumn{2}{|c|}{$\begin{array}{l}\text { Sri Lanka } \\
(n=6)\end{array}$} & \multicolumn{2}{|c|}{$\begin{array}{c}\text { Myanmar } \\
(n=11)\end{array}$} & \multicolumn{2}{|c|}{$\begin{array}{l}\text { Others } \\
(n=10)\end{array}$} & \multicolumn{2}{|c|}{$\begin{array}{l}\text { Total } \\
(n=88)\end{array}$} \\
\hline & No. & $\%$ & No. & $\%$ & No. & $\%$ & No. & $\%$ & No. & $\%$ \\
\hline $\begin{array}{l}\text { Formal means } \\
\text { of travel were } \\
\text { impossible/banned }\end{array}$ & 52 & 85.2 & 3 & 50.0 & 11 & 100.0 & 8 & 80.0 & 74 & 84.1 \\
\hline Other & 28 & 45.9 & 1 & 16.7 & 1 & 9.1 & 2 & 20.0 & 32 & 36.4 \\
\hline $\begin{array}{l}\text { Proper entry } \\
\text { would be rejected } \\
\text { at the border }\end{array}$ & 24 & 39.3 & 4 & 66.7 & 0 & 0.0 & 3 & 30.0 & 31 & 35.2 \\
\hline $\begin{array}{l}\text { I didn't want to be } \\
\text { sent back to my } \\
\text { country }\end{array}$ & 9 & 14.8 & 2 & 33.3 & 1 & 9.1 & 0 & 0.0 & 12 & 13.6 \\
\hline $\begin{array}{l}\text { No time to get } \\
\text { proper documents }\end{array}$ & 8 & 13.1 & 1 & 16.7 & 0 & 0.0 & 0 & 0.0 & 9 & 10.2 \\
\hline $\begin{array}{l}\text { I lost my genuine } \\
\text { documents }\end{array}$ & 0 & 0.0 & 1 & 16.7 & 0 & 0.0 & 0 & 0.0 & 1 & 1.1 \\
\hline \multirow[t]{2}{*}{ Other } & \multicolumn{2}{|c|}{$\begin{array}{l}\text { Afghanistan } \\
\qquad(\mathrm{n}=11)\end{array}$} & \multicolumn{2}{|c|}{$\begin{array}{l}\text { Sri Lanka } \\
(\mathrm{n}=5)\end{array}$} & \multicolumn{2}{|c|}{$\begin{array}{l}\text { Myanmar } \\
(\mathrm{n}=5)\end{array}$} & \multicolumn{2}{|c|}{$\begin{array}{l}\text { Others } \\
(n=4)\end{array}$} & \multicolumn{2}{|c|}{$\begin{array}{l}\text { Total } \\
(n=25)\end{array}$} \\
\hline & No. & $\%$ & No. & $\%$ & No. & $\%$ & No. & $\%$ & No. & $\%$ \\
\hline $\begin{array}{l}\text { I was following } \\
\text { the arrangements } \\
\text { made by my } \\
\text { smuggler }\end{array}$ & 14 & 50.0 & 0 & 0.0 & 0 & 0.0 & 2 & 100.0 & 16 & 50.0 \\
\hline $\begin{array}{l}\text { My status in } \\
\text { last country } \\
\text { of residence } \\
\text { was illegal- } \\
\text { perpetuating the } \\
\text { illegal nature of my } \\
\text { journey }\end{array}$ & 14 & 50.0 & 1 & 100.0 & 1 & 100.0 & 0 & 0.0 & 16 & 50.0 \\
\hline $\begin{array}{l}\text { Common to enter } \\
\text { illegally }\end{array}$ & - & - & - & - & - & - & - & - & - & - \\
\hline
\end{tabular}

Source: Transit migration survey $(2010,2012)(n=88)$.

Moreover, the shift towards illegality for those who began their journey legally usually occurred when entering or exiting Malaysia. Entering Indonesia illegally is also partly linked to the proportion of respondents who anticipated likely rejection by immigration authorities if they attempted to enter through formal channels ( 35.2 per cent). A visa restrictions index on the freedom of travel for citizens of each country (Henley \& Partners, 2013) ranked Myanmar and Sri Lanka lowly on its index at 86 and 88 respectively (out of 93 ); ${ }^{3}$ Afghanistan in particular was

3 There were only 93 rankings in the index because they included joint rankings. 
ranked lowest in the world at 93. Further, these countries are exempt from obtaining the 30-day visa on arrival (VOA) which would make travelling to Indonesia an onerous if not impossible process. The hard line taken by the Indonesian Government was highlighted in 2013 when Iran had their access to the 30-day VOA privilege removed. Up to then, Iran was the only major source country for asylum seekers with access to the 30-day VOA (Brown, 2013).

Further clarification from respondents revealed that clandestine entry was to avoid deportation to their home country, as they did not have to risk being rejected by immigration officials at the airport. The role of smugglers is again noted, with a small number of respondents $(n=16)$ indicating that they were only following their smuggler's instructions to enter Indonesia illegally; again, this seemed to be more prevalent for Afghan respondents. For some, that is, their illegal status continues throughout their journey, while others seek to enter undetected in order to avoid deportation back to their home countries if they were rejected at formal entry points. This latter appears to be quite an efficient strategy.

As shown in Figure 7.3, the majority of respondents (93.2 per cent) who deliberately entered Indonesia illegally did not encounter any border control or immigration authorities. This not only highlights the likely success of undocumented entry into Indonesia, but also perhaps is indicative of a less than efficient border control. Figure 7.4 shows the mode of transport used by respondents entering Indonesia. As anticipated, 86.6 per cent of all respondents entered Indonesia on a raft or boat, followed by 12.6 per cent who travelled by air.

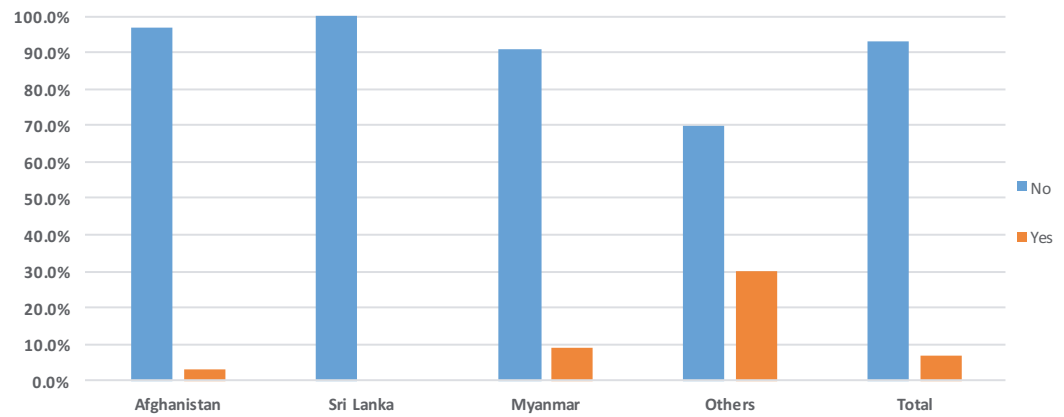

Figure 7.3: Encountering border control/immigration authorities when illegally entering Indonesia

Source: Transit migration survey $(2010,2012)(n=88)$. 


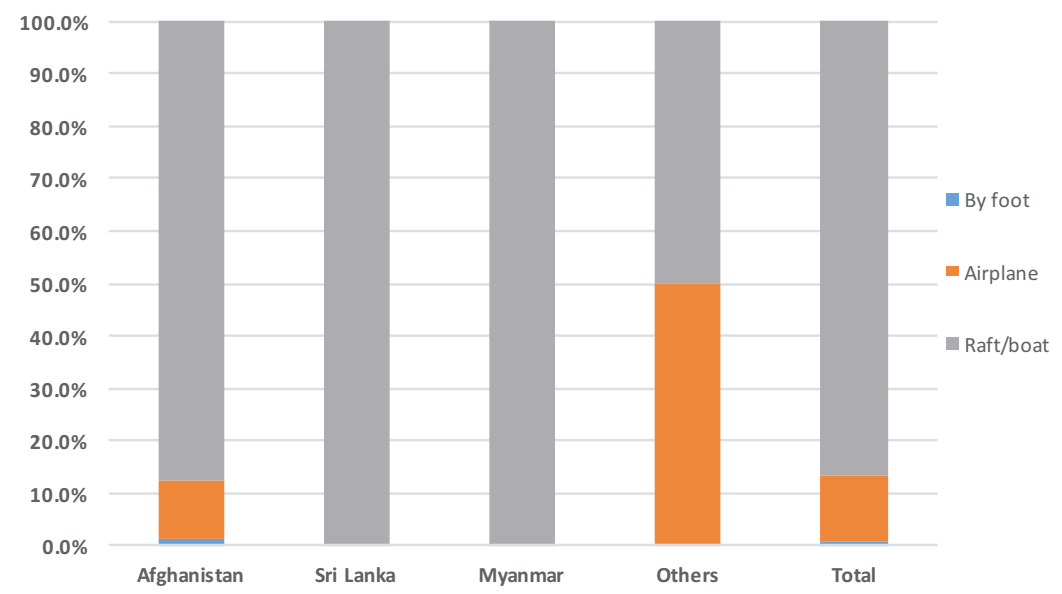

Figure 7.4: Mode of transport used to enter Indonesia

Source: Transit migration survey $(2010,2012)(n=119)$.

Sumatra plays a significant role in receiving asylum seekers: over half of respondents (57.7 per cent) indicated that they disembarked somewhere in Sumatra. Clearly, Sumatra's location is important: it is an island situated in Western Indonesia, of close proximity to Malaysia, and with the Strait of Malacca along its north-eastern shore separating it from the Malay Peninsula. This corridor of movement is well established and a complex industry of interconnected agents has developed to facilitate migration along this route. In addition to asylum seekers, illegal workers constitute another part of the irregular migration occurring in this region, with 200,000 to 300,000 Indonesians working in Malaysia estimated to have bypassed the regular migration channels in 2008 (Ford \& Lyons, 2011, p. 109).

There are elements of corruption, with accounts of Malaysian people smugglers working together with the Indonesian navy to facilitate the return of undocumented Indonesian migrant workers (Ford \& Lyons, 2013, pp. 216-17). Such examples contribute to the blurring of boundaries between legitimate and illegal practices which have led to the 'aspal' route, a greying of the illegal nature of labour migration of Indonesians to Singapore and Malaysia (Ford \& Lyons, 2011). In this context, it is easy to see how smuggling operations can flourish in the Riau Islands and other locations along the north-eastern shores of Sumatra and how they are a magnet for asylum seekers using Indonesia as a transit point. 


\section{The role of the migration industry}

It is important to acknowledge, however, that while it is possible to recognise some movements as being totally forced or voluntary, many migrations contain elements of both (Hugo, 1996). In the case of asylum seekers coming to Australia, for most respondents, the major reason impelling their migration was insecurity and fear of violence or war and conflict in the origin countries. But there were clearly also elements of choice involved in the decision-making process. Whether or not people move is clearly influenced by the social network of the potential movers and the extent to which they have family and friends in Australia. This is important in terms of both supply of information regarding the destination and assurance of support at the destination, as well as of the financing of the move itself. The nexus between the community in Australia and asylum seekers is important. Asylum seekers are in constant contact with their Australian contacts before and during the migration process, often using mobile phones.

However, it is crucial to recognise the pivotal role of the migration industry. Agents are a very important element in the asylum migration process. Very often, the agents are of the same nationality or ethnicity as the asylum seekers themselves. Almost all asylum seekers rely, to some extent, on people smugglers during at least some stage of the process, if not throughout the movement to Australia.

In most cases, it seems that people smugglers do not arrange the complete journey from the origin country to Australia, but rather one or more legs of the movement. The overall picture which emerges is not of an integrated international structure of tightly linked elements between origin and international destination, but one described by Missbach and Sinanu (2011, p. 66) as 'loose, temporary, acephalous networks', and by Içduygu and Toktas (2002, p. 46) as 'a loosely cast network consisting of hundreds of independent smaller units which cooperate along the way'.

Government officials and police in transit countries also play a role in the networks. Missbach and Sinanu (2011) point out that there is a contrast between Malaysia and Indonesia in this respect:

Unlike in Malaysia, where asylum seekers face massive repression by the local police and immigration authorities even if they hold UNHCR documents, the Indonesian authorities normally accept these documents. (p. 74) 
Throughout the corridors of movement, corrupt officials are a key element in the people smuggling process. The dangers that many asylum seekers face cannot be underestimated, and the personal tragedies that so frequently occur not only must be an important part of the narrative of asylum seekers, they must also (and they do) influence policy. It does need to be said also, however, that these corridors of movement do contain networks of support and communication which facilitate and support the migration.

In examining the role of the migration industry, it is crucial to recognise a number of its characteristics:

a. It did not arise in Indonesia in the 1990s purely to facilitate IMAs destined for Australia. It has a history extending over centuries.

b. The migration industry with Indonesia is very large and multilayered, from the involvement of international criminal organisations down to large cities with agents and local communities with subagents and sub-subagents.

c. There is a high level of complicity of government and government workers at all levels.

d. It is often linked to legal migration, with many agents being involved in both legal and illegal movement.

e. It is interlinked with family and regional networks.

f. It operates both for internal migration within Indonesia as well as for international movement.

g. It is extremely flexible, with workers in the industry able to diversify into other areas of activity if demand for their services in one area of migration should dry up. Accordingly, the industry can be very quick to respond to new opportunities and it cannot be killed off by destroying one avenue for undocumented migration (Munro, 2011).

h. The industry is embedded in local communities.

i. The industry has strong linkages with the fishing industry.

j. The migration industry has very strong, long historical connections with the Middle East and Malaysia, which have been utilised in facilitating the flow of intending IMAs.

k. In most cases, there is not a single agent; rather, migrants and intending migrants are passed through networks of agents at different points and often with new payments at each point. 
1. Co-ethnics play a key role, and in the case of asylum seekers they are often working together with Indonesian colleagues. Some of the co-ethnics are unsuccessful former asylum seekers. The preexisting Arab community in Indonesia has been the anchor around which these co-ethnic agents have developed.

$\mathrm{m}$. It is becoming increasingly professionalised.

The chains of migration-industry connections reaching to the areas which intending IMAs come from or pass through is an important element in understanding the movement of asylum seekers and irregular migrants. The connection with Malaysia is of particular importance, since most intending IMAs initially come to Kuala Lumpur. The migration industry has 'seeped into' and penetrated state institutes in both Malaysia and Indonesia.

\section{Life in transit}

There are around 10,000 asylum seekers and refugees currently in Indonesia registered with the United Nations High Commissioner for Refugees (UNHCR) and IOM. ${ }^{4}$ Table 7.3 lists the ratings of respondents on their living conditions in Indonesia. As shown below, more respondents rated living conditions to be bad or very bad (a combined 60.5 per cent of respondents), than good or very good (about one fifth of respondents, 21.9 per cent).

Respondents were also asked to indicate if they had any contact with Indonesian locals. As Figure 7.5 illustrates, two thirds of respondents (67.2 per cent) did not socialise with any local Indonesians. This was followed by 18.5 per cent of respondents who socialised on occasion, and 14.3 per cent who socialised on a regular basis.

4 This was as of February 2014. There have subsequently been significant changes with the International Labor Organization (ILO) and IOM detaining, for the first time, more than 2,000 asylum seekers and refugees. Nearly one in four detainees is a child (416 total, 216 of them unaccompanied). This is leading to crowding of several of the centres and some violence. The total number of refugees and asylum seekers registered with the UNHCR is the lowest since March 2013: 9,547, after 2,385 have abandoned their claim for asylum. 
Table 7.3: Negative experiences/abuses experienced by respondents

\begin{tabular}{|c|c|c|c|c|c|c|c|c|c|c|}
\hline \multirow[b]{2}{*}{$\begin{array}{l}\text { Freedom of } \\
\text { communication } \\
\text { totally denied }\end{array}$} & \multicolumn{2}{|c|}{$\begin{array}{l}\text { Afghanistan } \\
\qquad(\mathrm{n}=65)\end{array}$} & \multicolumn{2}{|c|}{$\begin{array}{c}\text { Sri Lanka } \\
(\mathrm{n}=26)\end{array}$} & \multicolumn{2}{|c|}{$\begin{array}{l}\text { Myanmar } \\
(n=12)\end{array}$} & \multicolumn{2}{|c|}{$\begin{array}{l}\text { Others } \\
(n=16)\end{array}$} & \multicolumn{2}{|c|}{$\begin{array}{c}\text { Total } \\
(\mathrm{n}=119)\end{array}$} \\
\hline & 25 & $38.5 \%$ & 12 & $46.2 \%$ & 2 & $16.7 \%$ & 5 & $31.2 \%$ & 44 & $37.0 \%$ \\
\hline $\begin{array}{l}\text { Freedom of } \\
\text { movement totally } \\
\text { denied }\end{array}$ & 20 & $30.8 \%$ & 13 & $50.0 \%$ & 1 & $8.3 \%$ & 4 & $25.0 \%$ & 38 & $31.9 \%$ \\
\hline None & 23 & $35.4 \%$ & 1 & $3.8 \%$ & 3 & $25.0 \%$ & 8 & $50.0 \%$ & 35 & $29.4 \%$ \\
\hline $\begin{array}{l}\text { Freedom of } \\
\text { movement partially } \\
\text { denied }\end{array}$ & 12 & $18.5 \%$ & 10 & $38.5 \%$ & 5 & $41.7 \%$ & 2 & $12.5 \%$ & 29 & $24.4 \%$ \\
\hline $\begin{array}{l}\text { Freedom of } \\
\text { communication } \\
\text { partially denied }\end{array}$ & 14 & $21.5 \%$ & 9 & $34.6 \%$ & 3 & $25.0 \%$ & 2 & $12.5 \%$ & 28 & $23.5 \%$ \\
\hline $\begin{array}{l}\text { Verbal/psychological } \\
\text { abuse }\end{array}$ & 12 & $18.5 \%$ & 5 & $19.2 \%$ & 1 & $8.3 \%$ & 2 & $12.5 \%$ & 20 & $16.8 \%$ \\
\hline Physical abuse & 12 & $18.5 \%$ & 2 & $7.7 \%$ & 3 & $25.0 \%$ & 2 & $12.5 \%$ & 19 & $16.0 \%$ \\
\hline $\begin{array}{l}\text { Money and personal } \\
\text { possessions were } \\
\text { 'confiscated' }\end{array}$ & 13 & $20.0 \%$ & 3 & $11.5 \%$ & 2 & $16.7 \%$ & 1 & $6.2 \%$ & 19 & $16.0 \%$ \\
\hline $\begin{array}{l}\text { Was searched } \\
\text { roughly }\end{array}$ & 8 & $12.3 \%$ & 2 & $7.7 \%$ & 1 & $8.3 \%$ & 3 & $18.8 \%$ & 14 & $11.8 \%$ \\
\hline $\begin{array}{l}\text { Imprisonment } \\
\text { without charges }\end{array}$ & 5 & $7.7 \%$ & 5 & $19.2 \%$ & - & - & - & - & 10 & $8.4 \%$ \\
\hline $\begin{array}{l}\text { Asked for bribes to } \\
\text { be treated well }\end{array}$ & 3 & $4.6 \%$ & 2 & $7.7 \%$ & - & - & - & - & 5 & $4.2 \%$ \\
\hline $\begin{array}{l}\text { Documents were } \\
\text { seized without } \\
\text { permission }\end{array}$ & 2 & $3.1 \%$ & 1 & $3.8 \%$ & - & - & 1 & $6.2 \%$ & 4 & $3.4 \%$ \\
\hline $\begin{array}{l}\text { Forced to engage in } \\
\text { activities against will }\end{array}$ & 1 & $1.5 \%$ & - & - & - & - & - & - & 1 & $0.8 \%$ \\
\hline Work without wages & 1 & $1.5 \%$ & - & - & - & - & - & - & 1 & $0.8 \%$ \\
\hline $\begin{array}{l}\text { I was not paid } \\
\text { accordingly for work }\end{array}$ & 1 & $1.5 \%$ & - & - & - & - & - & - & 1 & $0.8 \%$ \\
\hline
\end{tabular}

Source: Transit migration survey $(2010,2012)(n=119)$.

By and large, the majority of asylum seekers are quite isolated from local Indonesians. However, the social networks of asylum seekers evolve with the progression of their migration. Other migrants and detainees were cited as major sources of information by respondents, which illustrates how asylum seekers establish useful social networks with other migrants and asylum seekers. Moreover, their travel companions from one 
transit point to the next usually comprised of newly acquainted fellow asylum seekers who can be valuable sources of information, which again underlines how information gathering and sharing can improve in transit as asylum seekers learn en route.

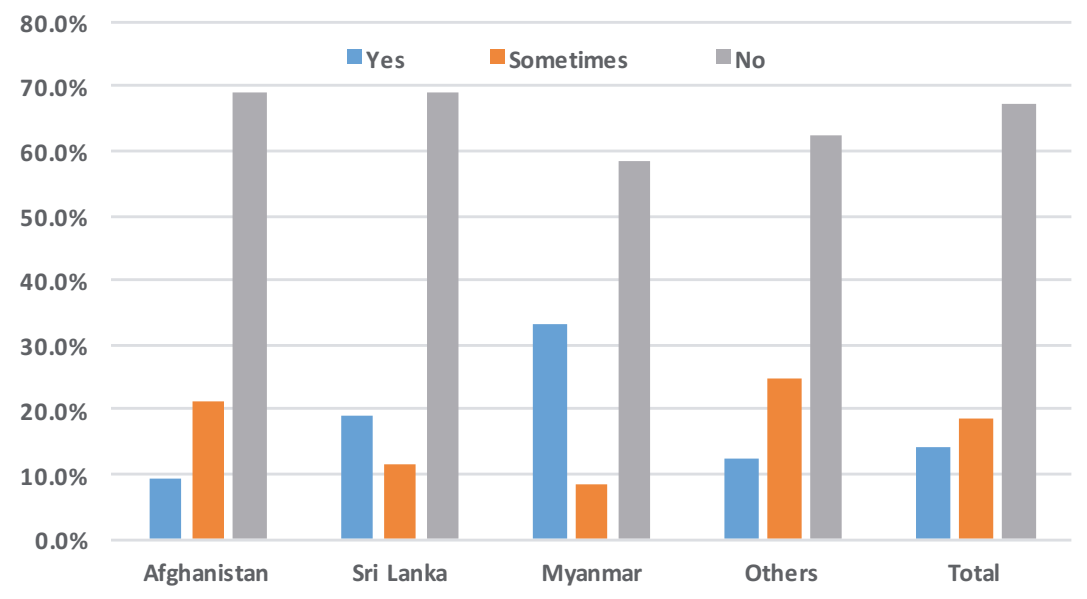

Figure 7.5: Socialising with local Indonesians

Source: Transit migration survey $(2010,2012)(n=119)$.

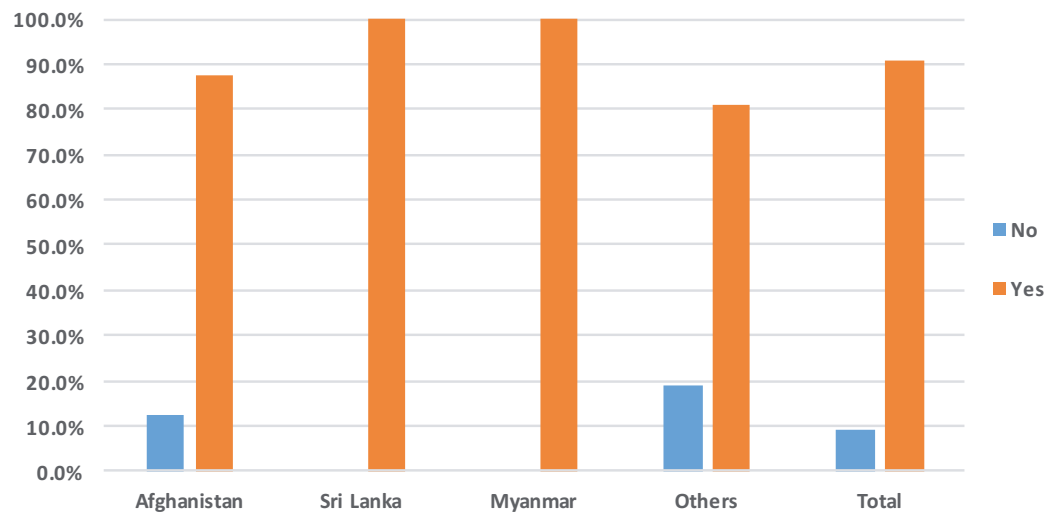

Figure 7.6: Have you applied for asylum in Indonesia?

Source: Transit migration survey $(2010,2012)(n=119)$.

Respondents were also asked to indicate what their status was in Indonesia and if they intended to irregularly onward migrate to Australia. As Figure 7.6 shows, the majority of respondents (90.8 per cent, $\mathrm{n}=108$ ) had applied for asylum in Indonesia. Of this proportion, only three respondents had their applications rejected, while the remainder were 
approved or still pending. This proportion of respondents were then asked to state the reasons which would motivate them to irregularly onward migrate despite their asylum claims being approved or awaiting determination. As Table 7.4 shows, the majority of respondents (86.7 per cent) indicated that they did not intend to irregularly onward migrate to Australia and were adamant that they would wait to be resettled. However, it is suspected that most of this group of respondents were likely to have impressed this on the field researcher for fear of any recourse that might jeopardise their asylum applications.

Table 7.4: Reasons for irregularly migrating to Australia

\begin{tabular}{|c|c|c|c|c|c|c|c|c|c|c|}
\hline \multirow[b]{2}{*}{$\begin{array}{l}\text { Don't intend to } \\
\text { escape }\end{array}$} & \multicolumn{2}{|c|}{$\begin{array}{l}\text { Afghanistan } \\
\quad(n=55)\end{array}$} & \multicolumn{2}{|c|}{$\begin{array}{c}\text { Sri Lanka } \\
(\mathrm{n}=25)\end{array}$} & \multicolumn{2}{|c|}{$\begin{array}{c}\text { Myanmar } \\
(n=12)\end{array}$} & \multicolumn{2}{|c|}{$\begin{array}{l}\text { Others } \\
(n=13)\end{array}$} & \multicolumn{2}{|c|}{$\begin{array}{c}\text { Total } \\
(n=105)\end{array}$} \\
\hline & 45 & $81.8 \%$ & 24 & $96.0 \%$ & 12 & $100.0 \%$ & 10 & $76.9 \%$ & 91 & $86.7 \%$ \\
\hline $\begin{array}{l}\text { Long wait for status } \\
\text { determination }\end{array}$ & 8 & $14.5 \%$ & 0 & $0.0 \%$ & 0 & $0.0 \%$ & 1 & $7.7 \%$ & 9 & $8.6 \%$ \\
\hline Other & 6 & $10.9 \%$ & 0 & $0.0 \%$ & 0 & $0.0 \%$ & 2 & $15.4 \%$ & 8 & $7.6 \%$ \\
\hline $\begin{array}{l}\text { Long wait for } \\
\text { resettlement }\end{array}$ & 3 & $5.5 \%$ & 1 & $4.0 \%$ & 0 & $0.0 \%$ & 1 & $7.7 \%$ & 5 & $4.8 \%$ \\
\hline $\begin{array}{l}\text { Want to go to a } \\
\text { specific country of } \\
\text { asylum }\end{array}$ & 4 & $7.3 \%$ & 0 & $0.0 \%$ & 0 & $0.0 \%$ & 1 & $7.7 \%$ & 5 & $4.8 \%$ \\
\hline Other & \multicolumn{2}{|c|}{$\begin{array}{l}\text { Afghanistan } \\
(n=6)\end{array}$} & \multicolumn{2}{|c|}{$\begin{array}{l}\text { Sri Lanka } \\
(n=0)\end{array}$} & \multicolumn{2}{|c|}{$\begin{array}{l}\text { Myanmar } \\
(n=0)\end{array}$} & \multicolumn{2}{|c|}{$\begin{array}{l}\text { Others } \\
(n=2)\end{array}$} & \multicolumn{2}{|c|}{$\begin{array}{l}\text { Total } \\
(\mathrm{n}=8)\end{array}$} \\
\hline $\begin{array}{l}\text { Poor conditions in } \\
\text { detention centre } \\
\text { (bad treatment/ } \\
\text { stressful) }\end{array}$ & 5 & $83.3 \%$ & - & - & - & - & 1 & $50.0 \%$ & 6 & $75.0 \%$ \\
\hline $\begin{array}{l}\text { Registered so } \\
\text { as to be safe } \\
\text { and I wouldn't } \\
\text { be harassed by } \\
\text { authorities }\end{array}$ & 1 & $16.7 \%$ & - & - & - & - & 1 & $50.0 \%$ & 2 & $25.0 \%$ \\
\hline
\end{tabular}

Source: Transit migration survey $(2010,2012)(n=105)$.

Nonetheless, it is worth examining the reasons that would motivate these respondents to further their illegal migration to Australia. As anticipated, a small number of respondents stated that a long wait for the determination of their asylum status $(n=9)$ and/or a long wait for resettlement $(n=5)$ would be a catalyst to irregularly onward migrate to Australia. Refugee status determination has been characterised as a period fraught with uncertainty, frustration and anxiety. Lengthy processing times, empty 
promises and perceived unresponsiveness of officials were mentioned. Asylum seekers feel trapped in a state of limbo whereby children are deprived of an education and adults denied gainful employment (Taylor \& Rafferty-Brown, 2010a, pp. 157-59; 2010b, pp. 561, 573). The indefinite nature of this process has been argued as a driving force behind those who elect to irregularly onward migrate to Australia as they 'are acting out of a strongly felt need to end this limbo, even at the risk of death' (Taylor \& Rafferty-Brown, 2010b, p. 561).

A small number of respondents $(n=5)$ also indicated that they were only interested in a specific country of asylum, which at this stage is Australia. Indonesia was a desirable location to apply for asylum, as its UNHCR division was perceived to have faster processing times in terms of status determination and the resettlement of refugees. Respondents who indicated that they only wanted to seek refuge in Australia were motivated by opportunities to receive an education, train or upgrade their skills and find employment. Additionally, some respondents also reflected that, through family reunification, they would, in the future, apply for their family members to join them in Australia.

Under other reasons, poor conditions in detention centres were likely to encourage some respondents $(n=6)$ to irregularly onward migrate to Australia. Conversely, a very small number $(\mathrm{n}=2)$ indicated that Australia was their primary destination and that registering with UNHCR was simply to obtain their attestation for safety reasons and avoid harassment from the Indonesian authorities.

Respondents were also asked to state their sources of financial support whilst in Indonesia. Given that asylum seekers and refugees do not have any rights to employment in Indonesia, it is unsurprising to see in Table 7.5 that none of the respondents had a full-time job, and only a small minority $(n=2)$ had a part-time job.

As expected, the majority (83.2 per cent) were reliant on support from UNHCR/IOM. Over half of respondents ( 55.5 per cent) also indicated that they had some money in hand and a small number relied on remittances from family and friends overseas $(\mathrm{n}=16)$ and from non-governmental organisations (NGOs) $(n=5)$. However, despite the lack of employment or income, respondents underlined the importance of sending remittances back to their home country, as illustrated in Figure 7.7. 
Table 7.5: Source of financial support in Indonesia

\begin{tabular}{|c|c|c|c|c|c|c|c|c|c|c|}
\hline \multirow[b]{2}{*}{ Full-time job } & \multicolumn{2}{|c|}{$\begin{array}{l}\text { Afghanistan } \\
\qquad(\mathrm{n}=65)\end{array}$} & \multicolumn{2}{|c|}{$\begin{array}{l}\text { Sri Lanka } \\
(\mathrm{n}=26)\end{array}$} & \multicolumn{2}{|c|}{$\begin{array}{l}\text { Myanmar } \\
(n=12)\end{array}$} & \multicolumn{2}{|c|}{$\begin{array}{l}\text { Others } \\
(n=16)\end{array}$} & \multicolumn{2}{|c|}{$\begin{array}{c}\text { Total } \\
(\mathrm{n}=119)\end{array}$} \\
\hline & - & - & - & - & - & - & - & - & - & - \\
\hline UNHCR/IOM & 51 & $78.5 \%$ & 25 & $96.2 \%$ & 12 & $100.0 \%$ & 11 & $68.8 \%$ & 99 & $83.2 \%$ \\
\hline Money in hand & 49 & $75.4 \%$ & 4 & $15.4 \%$ & 5 & $41.7 \%$ & 8 & $50.0 \%$ & 66 & $55.5 \%$ \\
\hline $\begin{array}{l}\text { Family and } \\
\text { friends abroad }\end{array}$ & 11 & $16.9 \%$ & 3 & $11.5 \%$ & - & - & 2 & $12.5 \%$ & 16 & $13.4 \%$ \\
\hline Other NGOs & 4 & $6.2 \%$ & 1 & $3.8 \%$ & - & - & - & - & 5 & $4.2 \%$ \\
\hline Part-time job & - & - & - & - & 1 & $8.3 \%$ & 1 & $6.2 \%$ & 2 & $1.7 \%$ \\
\hline
\end{tabular}

Source: Transit migration survey $(2010,2012)(n=119)$.

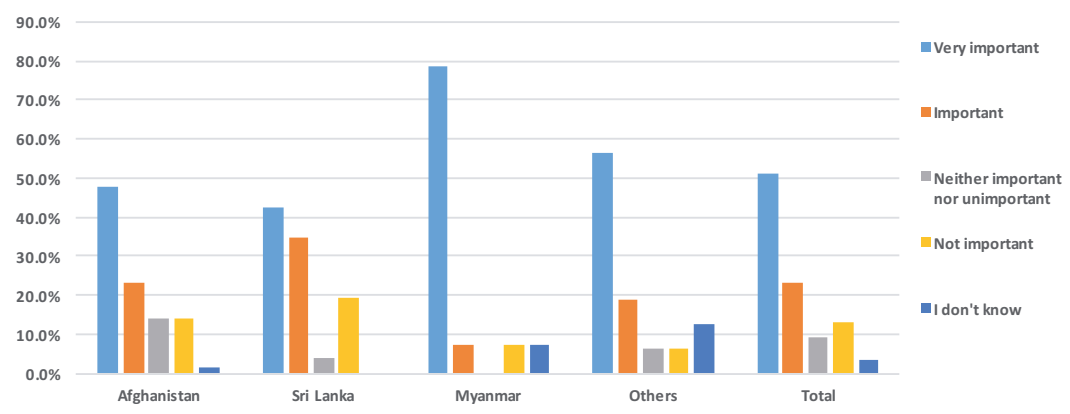

Figure 7.7: Importance of sending remittances to family back in home country

Source: Transit migration survey $(2010,2012)(n=121)$.

Just over half of respondents ( 51.2 per cent) indicated that it was very important for them to send remittances back to their respective home countries, and a further 23.1 per cent felt that it was important to do so. Less than one tenth (9.1 per cent) stated that it was neither important nor unimportant to do so. This reflects the pressure of financially supporting their families at home and repaying debts incurred in funding their migration, which fuels the likelihood of irregular onward migration to Australia.

Respondents were asked what reasons would encourage them to remain in Indonesia, if the Indonesian Government permitted permanent resettlement. Table 7.6 shows one fifth of respondents (20.2 per cent) indicated that they were motivated to further their journey and had no desire to remain in Indonesia. Conversely, 40.3 per cent of respondents indicated that friendly Indonesian locals were a positive factor for 
remaining in Indonesia. Although seeking protection was the underlying factor behind the selection of Australia as their final destination, economic reasons were also important in their decision-making process. As much as the main reasons for transiting in Indonesia were to flee from conflict and to live in peace, it does not necessarily mean that economic reasons were not relevant.

Table 7.6: Reasons encouraging settlement in Indonesia

\begin{tabular}{|c|c|c|c|c|c|c|c|c|c|c|}
\hline \multirow[b]{2}{*}{ Friendly locals } & \multicolumn{2}{|c|}{$\begin{array}{l}\text { Afghanistan } \\
\qquad(\mathrm{n}=65)\end{array}$} & \multicolumn{2}{|c|}{$\begin{array}{l}\text { Sri Lanka } \\
\qquad(\mathrm{n}=26)\end{array}$} & \multicolumn{2}{|c|}{$\begin{array}{l}\text { Myanmar } \\
(\mathrm{n}=12)\end{array}$} & \multicolumn{2}{|c|}{$\begin{array}{l}\text { Others } \\
(n=16)\end{array}$} & \multicolumn{2}{|c|}{$\begin{array}{c}\text { Total } \\
(n=119)\end{array}$} \\
\hline & 22 & $33.8 \%$ & 15 & $57.7 \%$ & 6 & $50.0 \%$ & 5 & $31.2 \%$ & 48 & $40.3 \%$ \\
\hline $\begin{array}{l}\text { It is a peaceful } \\
\text { country }\end{array}$ & 24 & $36.9 \%$ & 12 & $46.2 \%$ & 7 & $58.3 \%$ & 4 & $25.0 \%$ & 47 & $39.5 \%$ \\
\hline $\begin{array}{l}\text { No particular } \\
\text { reason }\end{array}$ & 23 & $35.4 \%$ & 4 & $15.4 \%$ & - & - & 4 & $25.0 \%$ & 31 & $26.1 \%$ \\
\hline $\begin{array}{l}\text { I don't want to } \\
\text { stay in Indonesia }\end{array}$ & 11 & $16.9 \%$ & 3 & $11.5 \%$ & 4 & $33.3 \%$ & 6 & $37.5 \%$ & 24 & $20.2 \%$ \\
\hline $\begin{array}{l}\text { Lack of money } \\
\text { to continue my } \\
\text { trip }\end{array}$ & - & - & 4 & $15.4 \%$ & 5 & $41.7 \%$ & - & - & 9 & $7.6 \%$ \\
\hline Other & 5 & $7.7 \%$ & - & - & 3 & $25.0 \%$ & 1 & $6.2 \%$ & 9 & $7.6 \%$ \\
\hline $\begin{array}{l}\text { Low cost of } \\
\text { living }\end{array}$ & 2 & $3.1 \%$ & 4 & $15.4 \%$ & 1 & $8.3 \%$ & 1 & $6.2 \%$ & 8 & $6.7 \%$ \\
\hline $\begin{array}{l}\text { Too tired to } \\
\text { continue my } \\
\text { journey }\end{array}$ & 2 & $3.1 \%$ & 3 & $11.5 \%$ & 2 & $16.7 \%$ & - & - & 7 & $5.9 \%$ \\
\hline $\begin{array}{l}\text { I was/am well } \\
\text { adjusted }\end{array}$ & 1 & $1.5 \%$ & 3 & $11.5 \%$ & 1 & $8.3 \%$ & - & - & 5 & $4.2 \%$ \\
\hline A good job & 0 & $0.0 \%$ & 2 & $7.7 \%$ & 3 & $25.0 \%$ & 0 & $0.0 \%$ & 5 & $4.2 \%$ \\
\hline Other & \multicolumn{2}{|c|}{$\begin{array}{l}\text { Afghanistan } \\
\qquad(\mathrm{n}=5)\end{array}$} & \multicolumn{2}{|c|}{$\begin{array}{l}\text { Sri Lanka } \\
\qquad(n=3)\end{array}$} & \multicolumn{2}{|c|}{$\begin{array}{l}\text { Myanmar } \\
\quad(n=0)\end{array}$} & \multicolumn{2}{|c|}{$\begin{array}{l}\text { Others } \\
(n=1)\end{array}$} & \multicolumn{2}{|c|}{$\begin{array}{l}\text { Total } \\
(n=9)\end{array}$} \\
\hline $\begin{array}{l}\text { Marriage to a } \\
\text { local }\end{array}$ & 2 & $3.1 \%$ & 1 & $3.8 \%$ & 0 & $0.0 \%$ & 0 & $0.0 \%$ & 3 & $2.5 \%$ \\
\hline $\begin{array}{l}\text { Indonesia } \\
\text { allows refugees } \\
\text { to live in the } \\
\text { community }\end{array}$ & 3 & $60.0 \%$ & 2 & $66.7 \%$ & - & - & 1 & $100.0 \%$ & 6 & $66.7 \%$ \\
\hline $\begin{array}{l}\text { Indonesia is an } \\
\text { Islamic country }\end{array}$ & 2 & $40.0 \%$ & 1 & $33.3 \%$ & - & - & - & - & 3 & $33.3 \%$ \\
\hline
\end{tabular}

Source: Transit migration survey $(2010,2012)(n=119)$. 


\section{Next steps of transiting migrants}

Analysing preferred destinations for resettlement sheds light on the decision-making process of asylum seekers and assists in understanding or deconstructing the labels of genuine asylum seekers or economic migrants attached to this particular group of migrants. Respondents who applied for asylum in Indonesia $(n=108)$ were asked to state the countries which they would like to be resettled in, and Figure 7.8 indicates their first, second and third choices.

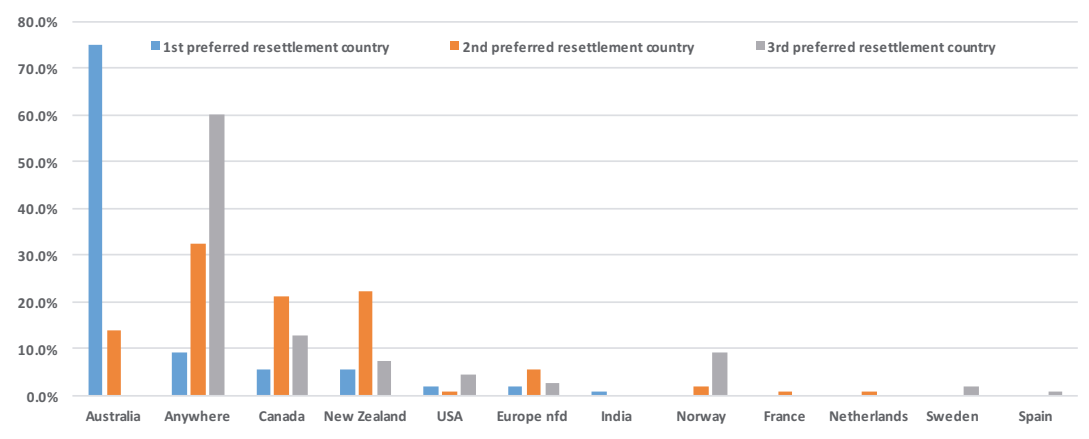

Figure 7.8: Preferred countries of resettlement

Source: Transit migration survey $(2010,2012)(n=108)$.

Note: 'nfd' means 'not further defined'.

A strong desire to be resettled in Australia was displayed by three quarters of respondents (75.0 per cent) indicating Australia as their first choice, while nearly one tenth (9.3 per cent) indicated that they would be happy to be resettled anywhere in the world. Remaining respondents stated Canada (5.6 per cent), New Zealand (5.6 per cent), USA (1.9 per cent) and Europe. Not further defined (1.9 per cent) and India ( 0.9 per cent) were the other preferred first choices. This finding is not surprising, given that all of the respondents were knowingly en route to Australia and had committed to Australia as their final destination. It is fair to assume that most respondents, at this near-final stage of their migration (i.e. transit in Indonesia), would nominate Australia as their preferred location. However, if respondents were asked this question before they commenced their journey, or at the early stages of their migration, Australia might not be as prominent. Nonetheless, beyond Australia as the most preferred destination, the willingness to be resettled in any country (as reflected in their second and third choices), and the fact that only a small proportion of respondents had second and third choices, suggests that attempts to dichotomise genuine from nongenuine refugees are perhaps too simplistic. 
Respondents reflected mixed reasons for leaving their respective home countries and for choosing Australia as a destination. While reasons relating to protection and escape from conflict and persecution can overlap with factors associated with employment, education or simply the opportunity to lead a better life, it would appear that for many respondents, the principal characteristic of a preferred resettlement country is to seek protection.

Any country that can guarantee freedom. (SL05TP1)

Any country, even Indonesia. (SL04TP1)

Canada, Australia, New Zealand. They are the same [in terms of safety, freedom and opportunities]. (AF03TP2)

Anywhere that I can get education and freedom. (AF10TP2)

\section{Onward migration from Indonesia}

Figure 7.9 shows that a small number of Afghan and Sri Lankan respondents have attempted this journey more than once. Irregular migration is a very costly affair, and Myanmese respondents are probably the least likely to be able to afford multiple attempts. Overall, however, it is evident that most respondents (95.9 per cent) have only attempted to make their way to Australia once.

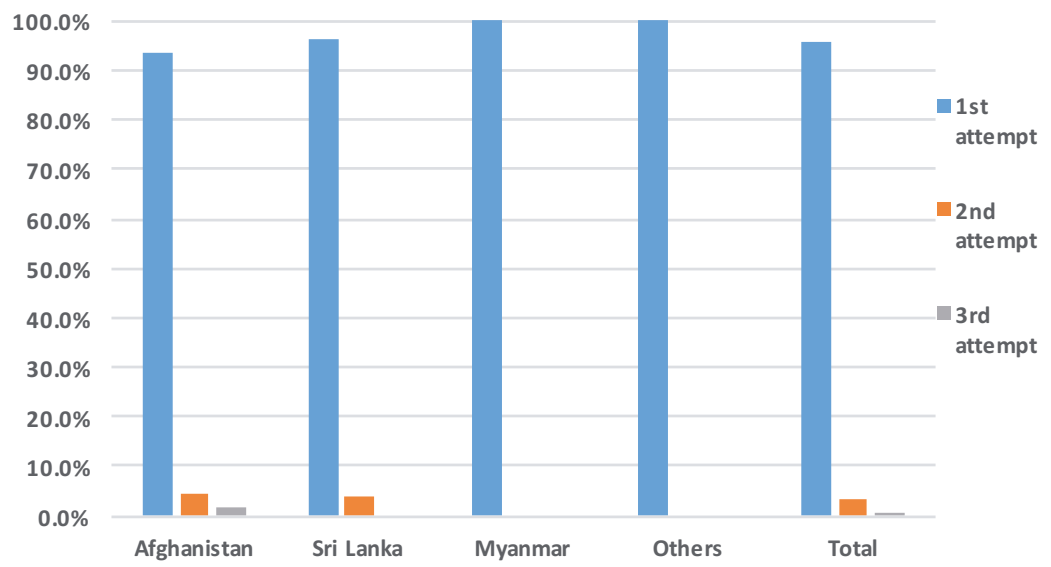

Figure 7.9: Number of attempts to Australia

Source: Transit migration survey $(2010,2012)(n=121)$. 
When it comes to making arrangements for the journey from Indonesia to Australia, it is clear that smugglers have a crucial role, as Table 7.7 shows. One third of respondents (32.8 per cent) engaged the services of smugglers, with 16.8 per cent of all respondents transiting in Indonesia engaging with a local smuggler only, 14.3 per cent engaging with their previous smuggler and local smuggler (i.e. same network) and a small number (1.7 per cent, $\mathrm{n}=2$ ) who used a smuggler based outside of Indonesia along with a local smuggler.

It would seem that almost two thirds of respondents ( 64.7 per cent) made arrangements for the journey to Australia while transiting in Indonesia. Smugglers and individual operators based in Indonesia are significant in the final leg of an asylum seeker's journey to Australia. The sample size does warrant caution, and while the findings are certainly not conclusive, they do suggest that while transnational smuggling networks can be quite efficient in getting asylum seekers to Indonesia, asylum seekers have to be resourceful in negotiating the final leg of their passage to Australia with smugglers based in Indonesia.

Table 7.7: Stakeholders assisting with migration to Australia by nationality

\begin{tabular}{|c|c|c|c|c|c|c|c|c|c|c|}
\hline \multirow[b]{2}{*}{$\begin{array}{l}\text { Previous and } \\
\text { local agent }\end{array}$} & \multicolumn{2}{|c|}{$\begin{array}{l}\text { Afghanistan } \\
\qquad(n=65)\end{array}$} & \multicolumn{2}{|c|}{$\begin{array}{c}\text { Sri Lanka } \\
(\mathrm{n}=26)\end{array}$} & \multicolumn{2}{|c|}{$\begin{array}{l}\text { Myanmar } \\
(n=12)\end{array}$} & \multicolumn{2}{|c|}{$\begin{array}{l}\text { Others } \\
(n=16)\end{array}$} & \multicolumn{2}{|c|}{$\begin{array}{c}\text { Total } \\
(n=119)\end{array}$} \\
\hline & 11 & $16.9 \%$ & 1 & $3.8 \%$ & - & - & 5 & $31.2 \%$ & 17 & $14.3 \%$ \\
\hline Myself & - & - & - & - & - & - & 1 & $6.3 \%$ & 1 & $0.8 \%$ \\
\hline $\begin{array}{l}\text { Family/relative/ } \\
\text { friend migrating } \\
\text { with me }\end{array}$ & - & - & - & - & - & - & - & - & - & - \\
\hline $\begin{array}{l}\text { Family/relative/ } \\
\text { friend in } \\
\text { Australia }\end{array}$ & - & - & - & - & - & - & - & - & - & - \\
\hline $\begin{array}{l}\text { Family/relative/ } \\
\text { friend abroad }\end{array}$ & - & - & - & - & - & - & - & - & - & - \\
\hline $\begin{array}{l}\text { Family/relative/ } \\
\text { friend in } \\
\text { Indonesia }\end{array}$ & - & - & - & - & - & - & - & - & - & - \\
\hline $\begin{array}{l}\text { Family/relative/ } \\
\text { friend at home }\end{array}$ & - & - & - & - & - & - & - & - & - & - \\
\hline $\begin{array}{l}\text { Smuggler in } \\
\text { Australia }\end{array}$ & - & & - & - & - & - & - & - & - & - \\
\hline $\begin{array}{l}\text { Smuggler } \\
\text { abroad and } \\
\text { local smuggler }\end{array}$ & 2 & $3.1 \%$ & - & - & - & - & - & - & 2 & $1.7 \%$ \\
\hline
\end{tabular}




\begin{tabular}{|c|c|c|c|c|c|c|c|c|c|c|}
\hline \multirow[b]{2}{*}{$\begin{array}{l}\text { A local } \\
\text { smuggler only }\end{array}$} & \multicolumn{2}{|c|}{$\begin{array}{l}\text { Afghanistan } \\
\qquad(n=65)\end{array}$} & \multicolumn{2}{|c|}{$\begin{array}{l}\text { Sri Lanka } \\
(\mathrm{n}=26)\end{array}$} & \multicolumn{2}{|c|}{$\begin{array}{c}\text { Myanmar } \\
(n=12)\end{array}$} & \multicolumn{2}{|c|}{$\begin{array}{l}\text { Others } \\
(n=16)\end{array}$} & \multicolumn{2}{|c|}{$\begin{array}{c}\text { Total } \\
(n=119)\end{array}$} \\
\hline & 17 & $29.2 \%$ & 1 & $3.8 \%$ & - & - & 2 & $12.5 \%$ & 20 & $16.8 \%$ \\
\hline $\begin{array}{l}\text { Smuggler at } \\
\text { home }\end{array}$ & - & - & - & - & - & - & - & - & - & \\
\hline $\begin{array}{l}\text { A smuggler } \\
\text { (unknown } \\
\text { location) }\end{array}$ & - & - & - & - & - & - & - & - & - & \\
\hline I don't know & - & - & - & - & - & - & - & - & - & - \\
\hline $\begin{array}{l}\text { Haven't } \\
\text { arranged } \\
\text { anything due to } \\
\text { detention }\end{array}$ & 33 & $50.8 \%$ & 24 & $92.3 \%$ & 12 & $100.0 \%$ & 8 & $50.0 \%$ & 77 & $64.7 \%$ \\
\hline $\begin{array}{l}\text { Was resettled } \\
\text { by UNHCR }\end{array}$ & 2 & $3.10 \%$ & - & - & - & - & - & - & 2 & $1.70 \%$ \\
\hline
\end{tabular}

Source: Transit migration survey $(2010,2012)(n=121)$.

Independent units, individuals, and local service providers are crucial. As Figure 7.10 shows, half of respondents $(\mathrm{n}=20)$ who managed to make arrangements to travel to Australia engaged the services of an Indonesian local (i.e. local service provider) to assist with some aspect of their journey.

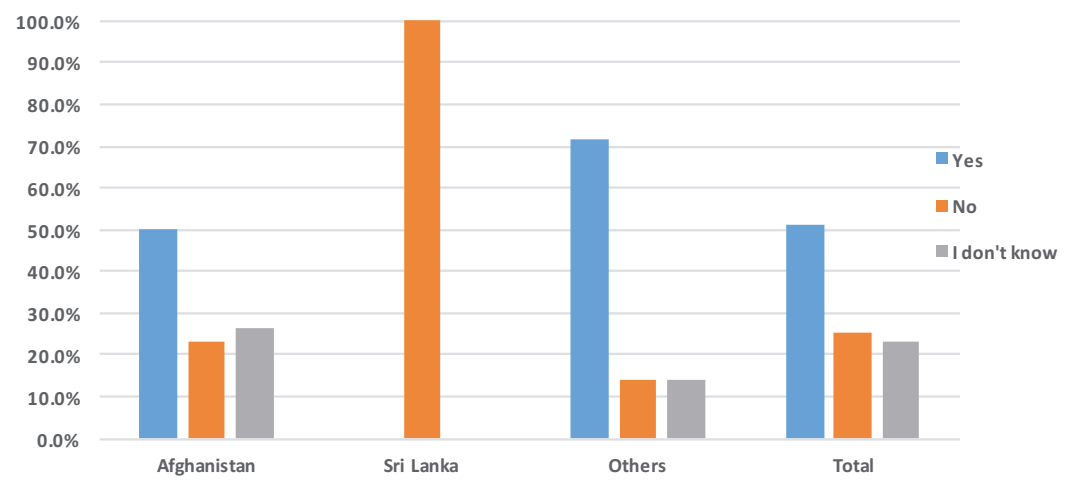

Figure 7.10: Intending IMAs to Australia: Use of an Indonesian local to arrange passage

Source: Transit migration survey $(2010,2012)(n=40)$. 
At a mean cost of USD5,364, the Indonesian-Australian leg is evidently the most expensive part of their journey, when considering that the mean cost of respondents' overall migration to Australia is USD10,310. Asylum seekers usually have a 'contract' or an agreement of sorts with smugglers in case their migration to Australia was unsuccessful, as indicated by the majority (70 per cent, $\mathrm{n}=28$ ) of respondents who used a smuggler (see Table 7.8).

Table 7.8: Contract or agreement with smuggler for failed migration to Australia

\begin{tabular}{|l|r|r|r|r|r|r|r|r|}
\hline & $\begin{array}{c}\text { Afghanistan } \\
(\mathrm{n}=30)\end{array}$ & \multicolumn{2}{c|}{$\begin{array}{c}\text { Sri Lanka } \\
(\mathrm{n}=2)\end{array}$} & \multicolumn{2}{|c|}{$\begin{array}{c}\text { Others } \\
(\mathrm{n}=8)\end{array}$} & \multicolumn{2}{|c|}{$\begin{array}{c}\text { Total } \\
(\mathrm{n}=40)\end{array}$} \\
\hline Yes & 21 & $70.0 \%$ & 2 & $100.0 \%$ & 5 & $62.5 \%$ & 28 & $70.0 \%$ \\
\hline No & 9 & $30.0 \%$ & 0 & $0.0 \%$ & 3 & $37.5 \%$ & 12 & $30.0 \%$ \\
\hline & $\begin{array}{c}\text { Afghanistan } \\
(\mathrm{n}=21)\end{array}$ & $\begin{array}{c}\text { Sri Lanka } \\
(\mathrm{n}=2)\end{array}$ & \multicolumn{2}{|c|}{$\begin{array}{c}\text { Others } \\
(\mathrm{n}=5)\end{array}$} & \multicolumn{2}{|c|}{$\begin{array}{c}\text { Total } \\
(\mathrm{n}=28)\end{array}$} \\
\hline Work in Australia & - & - & - & - & - & - & - & - \\
\hline $\begin{array}{l}\text { Full or partial return of money } \\
\text { for failed migration }\end{array}$ & 1 & $4.8 \%$ & 0 & $0.0 \%$ & 2 & $40.0 \%$ & 3 & $10.7 \%$ \\
\hline $\begin{array}{l}\text { Payment upon successful } \\
\text { migration }\end{array}$ & 3 & $14.3 \%$ & 0 & $0.0 \%$ & 0 & $0.0 \%$ & 3 & $10.7 \%$ \\
\hline $\begin{array}{l}\text { Down payment and } \\
\text { finalisation upon success }\end{array}$ & 8 & $38.1 \%$ & 2 & $100.0 \%$ & 1 & $20.0 \%$ & 11 & $39.3 \%$ \\
\hline $\begin{array}{l}\text { Payment managed by third } \\
\text { party based on outcome }\end{array}$ & 11 & $52.4 \%$ & 0 & $0.0 \%$ & 0 & $0.0 \%$ & 11 & $39.3 \%$ \\
\hline $\begin{array}{l}\text { Agent will attempt to resend } \\
\text { the migrant between 1-3 } \\
\text { more times }\end{array}$ & 12 & $57.1 \%$ & 0 & $0.0 \%$ & 3 & $60.0 \%$ & 15 & $53.6 \%$ \\
\hline
\end{tabular}

Source: Transit migration survey $(2010,2012)(n=40)$.

Respondents were also asked how long they had to wait in Indonesia before embarking on their journey to Australia. As Table 7.9 shows, more than half (a combined 42.5 per cent $[n=17]$ ) of respondents, excluding 'I don't know' results, transited in Indonesia for 4 weeks or less, compared with a combined 30 per cent $(n=12)$ who transited for a longer duration, ranging from 4 upwards towards 24 weeks. Overall, the waiting times in Indonesia are similar to those in previous transit countries like Malaysia and Thailand, with most respondents spending less than a month before continuing their migration to the next destination. 
Table 7.9: Duration spent in Indonesia before departing for Australia

\begin{tabular}{|c|c|c|c|c|c|c|c|c|}
\hline \multirow[b]{2}{*}{ Less than 1 week } & \multicolumn{2}{|c|}{$\begin{array}{l}\text { Afghanistan } \\
\qquad(\mathrm{n}=30)\end{array}$} & \multicolumn{2}{|c|}{$\begin{array}{l}\text { Sri Lanka } \\
\quad(n=2)\end{array}$} & \multicolumn{2}{|c|}{$\begin{array}{l}\text { Others } \\
(n=8)\end{array}$} & \multicolumn{2}{|c|}{$\begin{array}{c}\text { Total } \\
(n=40)\end{array}$} \\
\hline & 4 & $13.3 \%$ & - & - & 1 & $12.5 \%$ & 5 & $12.5 \%$ \\
\hline 1 to $<2$ weeks & 3 & $10.0 \%$ & - & - & 2 & $25.0 \%$ & 5 & $12.5 \%$ \\
\hline 2 to $<4$ weeks & 6 & $20.0 \%$ & - & - & 1 & $12.5 \%$ & 7 & $17.5 \%$ \\
\hline 4 to $<8$ weeks & 3 & $10.0 \%$ & 1 & $50.0 \%$ & - & - & 4 & $10.0 \%$ \\
\hline 8 to $<16$ weeks & 4 & $13.3 \%$ & - & - & 2 & $25.0 \%$ & 6 & $15.0 \%$ \\
\hline 16 to $<24$ weeks & 1 & $3.3 \%$ & - & - & 1 & $12.5 \%$ & 2 & $5.0 \%$ \\
\hline I don't know & 9 & $30.0 \%$ & 1 & $50.0 \%$ & 1 & $12.5 \%$ & 11 & $27.5 \%$ \\
\hline
\end{tabular}

Source: Transit migration survey $(2010,2012)(n=40)$.

In general, the majority of the embarkation locations stated by respondents in Table 7.10 tended to be around East Java and the Lesser Sunda Islands in South Eastern Indonesia, evidently favoured launching points due to their close proximity to Australia.

Table 7.10: Location from which respondents departed for Australia

\begin{tabular}{|c|c|c|c|}
\hline Location of departure & Province & Frequency & Per cent \\
\hline I don't know & - & 15 & $37.5 \%$ \\
\hline Unspecified hours of drive from Jakarta & - & 5 & $12.5 \%$ \\
\hline Kupang & $\begin{array}{l}\text { East Nusa } \\
\text { Tenggara }\end{array}$ & 5 & $12.5 \%$ \\
\hline Surabaya & East Java & 3 & $7.5 \%$ \\
\hline Lombok & $\begin{array}{l}\text { West Nusa } \\
\text { Tenggara }\end{array}$ & 3 & $7.5 \%$ \\
\hline Jakarta & Jakarta & 3 & $7.5 \%$ \\
\hline Mataram & Central Java & 2 & $5 \%$ \\
\hline Unspecified hours of drive from Bogor & - & 1 & $2.5 \%$ \\
\hline Sumbawa Island & $\begin{array}{l}\text { West Nusa } \\
\text { Tenggara }\end{array}$ & 1 & $2.5 \%$ \\
\hline Cilacap & Central Java & 1 & $2.5 \%$ \\
\hline Bali & Bali & 1 & $2.5 \%$ \\
\hline
\end{tabular}

Source: Transit migration survey $(2010,2012)(n=40)$.

Respondents were asked if they had any intentions to return to their home countries after resettlement in Australia. As Figure 7.11 shows, only a small number of respondents ( 10.5 per cent, $\mathrm{n}=9$ ) intended to return to their 
home country, compared with 41.0 per cent who did not. This indicates that there is a possibility that some refugees, even after resettlement in Australia, would voluntarily return to their home countries in the future.

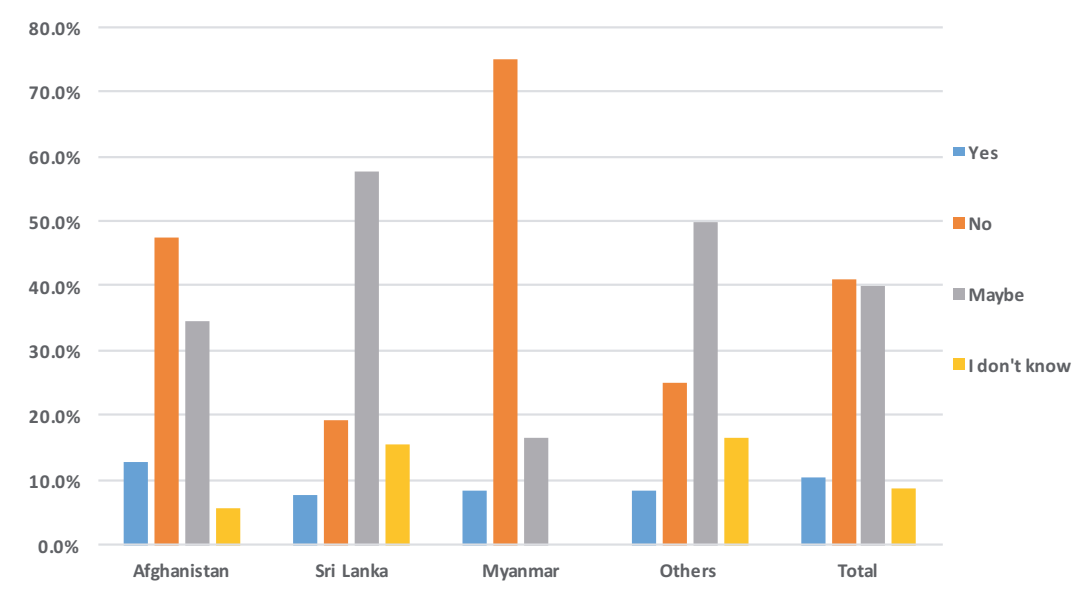

Figure 7.11: Intention to return to home country after resettlement

Source: Transit migration survey $(2010,2012)(n=105)$.

Some 85.1 per cent of respondents $(n=103)$ in Figure 7.12 below who indicated that in spite of negative experiences they have had with irregularly migrating, they would still have migrated even if they knew of the difficulties before leaving their home countries.

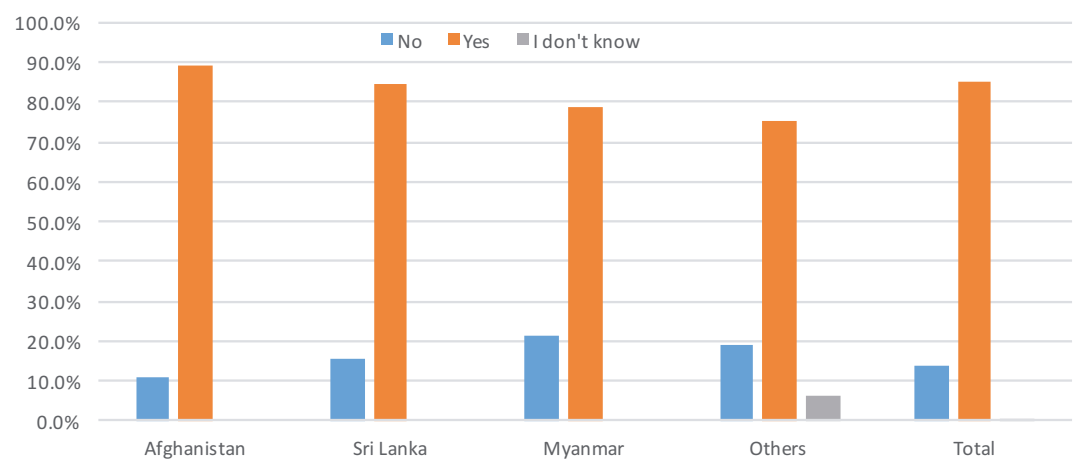

Figure 7.12: Would they still have migrated if they had known of the difficulties of irregular migration?

Source: Transit migration survey $(2010,2012)(n=121)$. 


\section{Conclusion}

The study found that the majority of respondents would enter Indonesia illegally, often by boat. There were a variety of reasons for this, but the main factor was simply their inability to travel legally. Their migration status might have been legal from the beginning of their journey, but shifted towards illegality in Thailand or Malaysia. For some, entering illegally was a strategy to avoid detection at official ports or channels, so as to eliminate the possibility of deportation to their home countries. The porous borders of Indonesia are further underlined, as the majority of asylum seekers who entered illegally were able to do so undetected. Moreover, respondents indicated that the Riau Islands and parts of Sumatra were their landing points—areas where Indonesian labour migrants are also smuggled to and from Malaysia and Singapore, underscoring the challenges in addressing the arrival of asylum seekers in Indonesia.

Life in Indonesia as indicated by respondents is generally poor. Although respondents had access to services, the quality of education and housing was poor. The majority of respondents were also quite isolated and did not socialise with Indonesians. Asylum seekers might be open to settling in Indonesia; however, poor living conditions, indefinite processing and resettlement times and negative experiences can drive asylum seekers to onward migrate to Australia.

While smugglers play a significant role, their networks seem to be weaker in Indonesia. Respondents transiting through Thailand and Malaysia often used the same smuggling network, whereby the smuggler used to travel from their last transit point to Malaysia would arrange for another smuggler in Malaysia to assist with the migration. However, there were fewer respondents who used the same network of agents in Indonesia. This is not only indicative of weaker transnational smuggling networks in Indonesia, but also underlines the importance of independent smugglers as well as independent units or local service providers assisting with other aspects of the migration.

The concept of transit migration is problematic, conceptually and politically, but it refers to a phenomenon of increasing significance in the Asian region where migration is both a cause and effect of rapid economic growth. However, in several countries in the region, governance issues, lack of institutional and human capacity, excessive rent taking and transaction 
costs dilute migration's potential positive developmental impacts, and in this context, as this study has shown, irregular migration and transiting is likely to increase in scale and impact.

\section{Reference list}

Brown, H. (2013). Indonesia to change visa requirements for Iranians entering the country following request from PM Kevin Rudd. Retrieved from ABC News: www.abc.net.au/news/2013-07-18/ indonesia-to-change-visa-requirements-for-iranians/ 4829434.

Düvell, F., Triandafyllidou, A., \& Vollmer, B. (2008). Ethical issues in irregular migration research. Cladestino Project. Retrieved from www.compas.ox.ac.uk/media/PR-2008-Clandestino_Ethics.pdf.

Ford, M., \& Lyons, L. (2011). Travelling the Aspal route: Grey labour migration through an Indonesian border town. In Aspinall, E., \& van Klinken, G. (Eds), The state and illegality in Indonesia (pp. 107-122). Leiden: Kitlv Press.

Ford, M., \& Lyons, L. (2013). Outsourcing border security: NGO involvement in the monitoring, processing and assistance of Indonesian nationals returning illegally by sea. Contemporary Southeast Asia, 35(2), 215-34. doi.org/10.1355/cs35-2d

Henley \& Partners. (2013). The Henley \& Partners Visa Restriction Index 2013. Jersey: Author.

Hugo, G. J. (1996). Environmental concerns and international migration. International Migration Review, 30(1), 105-31. doi.org/ $10.2307 / 2547462$

Hugo, G. J. (2011). Economic, social and civic contributions of first and second generation humanitarian entrants. Canberra: Department of Immigration and Citizenship.

Hugo, G. J., \& Dissanayake, L. (2014). The process of Sri Lankan migration to Australia focusing on irregular migrants seeking asylumstage 1. First draft of a report presented to the collaborative research program on the international movement of the people, Department of Immigration and Border Protection and Crawford School of Public Policy. Canberra: The Australian National University. 
Hugo, G. J., \& Napitupulu, C. J. (2015). Boats, borders, and ballot boxes: Asylum seekers on Australia's northern shore. In van der Velde, M., \& van Naerssen, T. (Eds), Mobility and migration choices: Thresholds to crossing borders (pp. 213-34). London: Routledge.

Içduygu, A., \& Toktas, S. (2002). How do smuggling and trafficking operate via irregular border crossings in the Middle East? Evidence from fieldwork in Turkey. International Migration, 40(6), 25-54. doi.org/10.1111/1468-2435.00222

Jayasuriya, D., \& McAuliffe, M. (2013). Placing recent Sri Lankan maritime arrivals in a broader migration context. Irregular Migration Research Program, occasional paper series 02. Canberra: Department of Immigration and Border Protection. Retrieved from www.border. gov.au/ReportsandPublications/Documents/research/placing-recentsri-lankan-maritime-arrivals-broader-migration-context.pdf.

Jones, S. (2000). Making money off migrants. Hong Kong: Asia 2000 Limited.

Kunz, E. F. (1973). The refugee in flight: Kinetic models and forms of displacement. International Migration Review, 7(2), 125-46. doi.org/ $10.2307 / 3002424$

Lander, B. (1996, 1 June). Indonesia: Far from paradise. Refugees Magazine, 104. Retrieved from www.unhcr.org/publications/ refugeemag/3b558c2a4/refugees-magazine-issue-104-unhcrs-worldindonesia-far-paradise.html.

Ley, D., \& Kobayashi, A. (2005). Back to Hong Kong: Return migration or transnational sojourn? Global Networks, 5(2), 111-27. doi.org/ 10.1111/j.1471-0374.2005.00110.x

Missbach, A. (2013). Waiting on the islands of 'stuckedness': Managing asylum seekers in island detention camps in Indonesia from the late 1970s to the Early 2000s. ASEAS-Austrian Journal of South-East Asian Studies, 6(2), 281-306.

Missbach, A., \& Sinanu, F. (2011). 'The scum of the earth?' Foreign people smugglers and their local counterparts in Indonesia. Journal of Current Southeast Asian Affairs, 30(4), 57-87. 
Munro, P. (2011). People smuggling and the resilience of criminal networks in Indonesia. Journal of Policing, Intelligence and Counter Terrorism, 6(1), 40-50.

Skrobanek, S., Boonpakdi, N., \& Janthakeero, C. (1997). The traffic in women: Human realities of the international sex trade. London and New York: Zed Books.

Taylor, S., \& Rafferty-Brown, B. (2010a). Difficult journeys: Accessing refugee protection in Indonesia. Monash University Law Review, 36(3), $138-61$.

Taylor, S., \& Rafferty-Brown, B. (2010b). Waiting for life to begin: The plight of asylum seekers caught by Australia's Indonesian solution. International Journal of Refugee Law, 22(4), 558-92. doi.org/10.1093/ ijrl/eeq034

United Nations High Commissioner for Refugees. (2014). UNHCR Indonesia-Fact Sheet, March 2014. Retrieved April 5, 2014 from www.unhcr.org/50001bda9.pdf.

United Nations Office on Drugs and Crime. (2009). Smuggling of migrants from India to Europe and in particular to UK: A study on Tamil Nadu. New Delhi: Author. Retrieved from www.unodc.org/documents/ human-trafficking/Smuggling_of_Migrants_from_India.pdf. 
This text is taken from A Long Way to Go: Irregular Migration Patterns, Processes, Drivers and Decision-making, edited by Marie McAuliffe and Khalid Koser, published 2017 by ANU Press, The Australian National University, Canberra, Australia.

dx.doi.org/10.22459/LWG.12.2017.07 